\title{
Descriptive Analysis of Environmental Performance, Sustainability Report, and Access to Finance
}

\author{
Ninditya Nareswari ${ }^{1, *}$ Geodita Woro Bramanti ${ }^{2}$, Maydawati Fidellia Gunawan ${ }^{3,}$ \\ Aang Kunaifi ${ }^{4}$, Nugroho Priyo Negoro ${ }^{5}$ \\ 1,2,3,4,5 Department of Business Management, Faculty of Creative Design and Digital Business, Institut Teknologi \\ Sepuluh Nopember \\ "Corresponding author. Email: geodita.bramanti@gmail.com
}

\begin{abstract}
This research aims to identify environmental performance, role of external assurance in sustainability reports, financial access, the quality of sustainability report disclosure and external assurance of a company. The samples are Indonesia non-financial public companies which are listed in the Performance Rating Assessment Program on Environment Management (Program Penilaian Peringkat Kinerja Perusahaan/PROPER) from 2014 to 2019. Using descriptive analysis, this research finds a fairly good environmental performance and an adequate performance of environmental management efforts as required from the observed sample. It also indicates that more than $78 \%$ of companies during the year of observation tend to not disclose separate sustainability reports. In addition, the lack of urgency in disclosing separate sustainability reports also reflected on the companies tendency of not using external assurance during the reporting process. This research also showed that financial access of the observed companies has various values with a fairly high value of standard deviation. Furthermore, this research suggests an analysis of the influence and correlation between variables used in this research as potential future studies.
\end{abstract}

Keywords: environmental performance, quality of sustainability report, external assurance, quality of external assurance, descriptive analysis.

\section{INTRODUCTION}

Environmental aspect has the most significant function in life sustainability. Currently, global environmental conditions are showing a drastic decline, which is characterized by the emergence of environmental problems, such as high levels of pollution, greenhouse gas (GHG) effect, global warming, and the threat of ecosystem extinction. These various problems are caused by activities from various sectors, especially by the nonfinancial sector.

As one of G20 members, Indonesia contributed in signing the first Nationally Determined Contribution (NDC) document in October 2016. Thus, it shows Indonesia's commitment to reduce the country's emissions to $29 \%$ with their own efforts and to $41 \%$ with support of international cooperation [1] . Based on the Climate Transparency Report, in 2020, greenhouse gas (GHG) emissions in Indonesia have increased significantly since 1990 , in which it reached the level of $581 \mathrm{MtCO} 2$ in 2019. The industrial sector is still the largest contributor to
Gross Domestic Product (GDP) in 2018 [2]. As the industry experienced a rapid growth, it might also affect the increase of environmental problems [3].

As part of the commitment in reducing the country's emissions, Indonesian Ministry of Environment and Forestry developed a program named Performance Rating Assessment Program on Environment Management or Program Penilaian Peringkat Kinerja Perusahaan dalam Pengelolaan Lingkungan (PROPER). This program was created to evaluate companies compliance and environmental management performance through incentives and disincentives. Previous research highlighted that companies with good environmental management rarely have problems in their financial access [4]. It is also said that they could get financial sources from third parties, both from financial institutions or investors, easier in general. Companies with good environmental management are in line with Central Bank of Indonesia Regulation 14/15/PBI/2012 and 15/28/DPNP 2013, which 
indicates the importance of environmental management level carried out by a company to successfully obtain credit facility approval.

Sustainability report is a public report issued by a company to provide information about the company's position in three dimensions, such as economic, social, and environmental dimension [5]. Based on Indonesia Law no. 40 year 2007 on the limited liability company, companies listed in IDS have the responsibility to report their sustainability information. However, the current law only requires companies to provide the sustainability information within the annual report. Thus, disclosing separate reports is still counted as voluntary in Indonesia. The Financial Services Authority (OJK) recorded that by the end of 2016, only 49 IDX listing companies published sustainability reports, in which $71 \%$ were listed as non-financial sector companies [6].

Sustainability reports are considered as reliable, when they provide high quality information. According to García-Sánchez et al. [7], a high quality sustainability report is when it meets specific guidelines during its reporting to publication process, and includes a qualified external assurance during the reporting process. Other researchers also conclude sustainability reports as reliable when it has a report assurance [8] [9], also whether the report had fulfilled the scoring of the environmental and social measurement index model [10]. In line with research conducted by García-Sánchez et al (2019), this research examines sustainability reports based on the quality of certain information in the report, the presence of an external assurance on the report, and the quality of the external guarantor.

This research provides an overview and knowledge of environmental performance, disclosure of sustainability reports, and financial access by non-financial public companies in Indonesia from 2014 to 2019 . This research can be considered to various parties and for the need for further research.

\section{LITERATURE REVIEW}

\subsection{Environmental Performance}

Environmental performance is a mechanism for a company in order to voluntarily integrate its awareness of the environment in operating business activities and while interacting with their stakeholders [11]. Environmental performance measures a company's activities that impact the natural environment and also the company's surroundings. The result of this mechanism indicates the rate of concern a company has in terms of environmental management in their business activities. High environmental performance led to increased legitimacy, reduced information asymmetry and possible agency costs, which will give an impact to an increase in the supply of capital and relieve the company's financing constraints [12].

In Indonesia, the Ministry of Environment and Forestry established the Performance Rating Assessment Program on Environment Management (PROPER) in order to encourage companies participation in environmental management. PROPER is an evaluation to the compliance and performance of a person in charge within a business and/or an activity, specifically in terms of controlling pollution and/or environmental damage, as well as managing hazardous and toxic waste [13]. This assessment will rank companies in 5 (five) colors, namely gold, green, blue, red, and black based on the result. The use of colors in PROPER results is intended to ease the public in absorbing the published information [14]. Gold rating companies indicate the performance of environmental management within the companies exceeds the requirements, have consistently demonstrated environmental excellence in the production or service process, have conduct a great business ethic and are responsible for the community. Companies with a green rating indicate that their environmental management has exceeded the required regulations through the implementation of the environmental management system, performs an efficient use of resources, and has a good implementation of social responsibility efforts. Blue rating companies showed that the company has performed adequate environmental management efforts according to the requirements. Meanwhile, companies with red and black ratings indicate that they have not carried out environmental management according to the requirements, or even carried out activities that damage the environment. The results of the company's performance appraisal ratings are announced and published regularly to the public. 
Thus, the ranking results could give an impact to enhance or damage the company's reputation [15].

\subsection{Sustainability Report}

A sustainability report is a public report that depicts a company's position and activities in terms of economic, social, and environmental dimensions [5]. This report provides a statement of policies, objectives, and development on environmental achievements within the company [16]. In addition, it also presents organizational and governance values, as well as the company's commitments to sustainable development [17]. As the companies have responsibility to their internal and external stakeholders, this report plays an important role in disclosing information regarding company's contributed performance in maintaining sustainability.

Sustainability reports are able to show the actual sustainability performance within companies [18]. In practice however the disclosure of sustainability reports in Indonesia is still conducted voluntarily, which means there's only a few that willingly disclose the reports. Even though the disclosure of this report could help companies to set goals, measure their performance, and manage change in operational activities to become more sustainable [17]. In addition, the disclosure of sustainability reports has the potential to reduce the company's financial constraints [19].

The guideline used as a standard for preparing sustainability reports by the majority of companies or organizations is the Global Reporting Initiatives (GRI) sustainability report guidelines. This guideline includes reporting principles, disclosure of reporting standards, and guidelines in preparing sustainability reports for companies so that they can produce reliable, relevant, and more standardized information. There are two standards of sustainability report disclosure based on the Global Reporting Initiatives (GRI) such as general and specific standards.

The disclosure quality is important as the company's stakeholders use this report to plan appropriate decisions and actions for the company. Disclosure with low quality could impact the investors and other external parties to not being able to capture reporting information. The higher the quality in disclosing reports means the possibility of difference in the information is lowered. According to G4 guidelines, a sustainability report has a high quality if it meets the following six principles, which are, the principles of balance, comparability, accuracy, timeliness, clarity, and reliability. [7] states that a sustainability report is considered as a high quality one, if it meets the guidelines for preparation or the GRI guidelines, and presents specific information. Research by [10] highlighted the criteria of qualified sustainability reports, which include the need to meet the scoring model of the environmental and social measurement index. Meanwhile, research by [8] and [9] measure the quality of sustainability reports based on the availability of external assurance for sustainability reports.

In order to increase the reliability and credibility of the sustainability report information, an external assurance role is essential. External assurance has the ability to provide new perspectives and opinions that are more objective and impartial, which then enables the company to increase trust from report users and also help the company in making decisions. However, including an external assurance during the disclosure of sustainability report is not required or voluntarily based on a company's need. The decision to include an external assurance in the reporting of a company is influenced by the report disclosure and the type of business industries [20]. The quality of an external assurance can be measured through the quality of the assurance statement. There are few standards that can be used by external guarantors in providing assurance statements, including the AA1000AS and ISAE3000 standards.

\subsection{Financial Access}

Financial access shows the company's ability to obtain financial resources [7]. Companies with access to finance indicate the possibility that these companies have access to financial services, including credit, deposits, payments, and other services. According to [4], easy access to finance is characterized by low financial constraints. In line with the research of [4], research by [21] also highlighted that better financial access can reduce the company's financial constraints which refers to market frictions that can prevent company funding.

In operating business activities, financial access is an important factor for companies, as 
proven by several previous studies. Financial access affects the company's growth rate, in which companies with lower financial constraints would experience faster growth than the one with higher financial constraints. In addition, financial access also influences various company decisions, such as company investment or divestment decisions, the decision of company capital structure, cash management policies, company export behavior, and the intensity of research and development activity within a company [22]. Several general indices can be used to measure a company's financial access, such as the KZ index by [23], the WW index by [24], and also the SA index by [25]. This research applied the KZ index to measure the company's financial access.

\section{METHOD}

For the analysis support, this research uses secondary data from PROPER, company's sustainability report and annual report. Descriptive analysis is used to identify a company's performance in environmental management, disclosure of separate sustainability reports and its quality, the presence or absence of external assurance in the sustainability report, the quality of the external assurance, and company's financial access. Table 1 presents the operational definition of each variable. The samples used in this research are Indonesia non-financial companies which are listed in PROPER from 2014 to 2019. During the six years of this research observation period, there are 501 observations used. This research used STATA to conduct the descriptive analysis.

Table 1. Operational Definition of Variables

\begin{tabular}{|l|l|l|l|}
\hline \multicolumn{1}{|c|}{ Variable } & $\begin{array}{c}\text { Operational } \\
\text { Definition }\end{array}$ & $\begin{array}{c}\text { Measurement } \\
\text { Indicator }\end{array}$ & References \\
\hline $\begin{array}{l}\text { Environmental } \\
\text { Performance } \\
\text { (EP) }\end{array}$ & $\begin{array}{l}\text { Environmental } \\
\text { management } \\
\text { performed by } \\
\text { the company }\end{array}$ & $\begin{array}{l}\text { PROPER } \\
\text { ratings }\end{array}$ & {$[13]$} \\
\hline $\begin{array}{l}\text { Sustainability } \\
\text { Report } \\
\text { Disclosure } \\
\text { Quality } \\
\text { (SRDQ) }\end{array}$ & $\begin{array}{l}\text { The level of } \\
\text { application on } \\
\text { Sustainability } \\
\text { Report based on } \\
\text { GRI guidelines }\end{array}$ & Scoring Level & [7] \\
\hline
\end{tabular}

\begin{tabular}{|l|l|l|l|}
\hline & $\begin{array}{l}\text { Availability of } \\
\text { external } \\
\text { Assurance of } \\
\text { Sustainability } \\
\text { Report (EA) } \\
\text { sustainability } \\
\text { report }\end{array}$ & $\begin{array}{l}\text { Valued as “1”, } \\
\text { if available, and } \\
\text { "0" otherwise }\end{array}$ & [7] \\
\hline $\begin{array}{l}\text { Quality of } \\
\text { External } \\
\text { Assurance } \\
\text { (AQ) }\end{array}$ & $\begin{array}{l}\text { The level of } \\
\text { external } \\
\text { assurance used } \\
\text { based on the } \\
\text { results of the } \\
\text { assurance } \\
\text { statement } \\
\text { generated in the } \\
\text { report }\end{array}$ & $\begin{array}{l}\text { Based on } \\
\text { scoring context } \\
\text { index } \text { of } \\
\text { SAE3000 } \\
\text { AA1000AS and } \\
\text { standards }\end{array}$ & [26] [27] \\
\hline $\begin{array}{l}\text { Financial } \\
\text { Access (KZ) }\end{array}$ & $\begin{array}{l}\text { The size of the } \\
\text { company's } \\
\text { financial } \\
\text { constraints }\end{array}$ & KZ index & [23] \\
\hline
\end{tabular}

\section{RESULT AND DISCUSSION}

The descriptive analysis presented includes the total number of observations, mean, standard deviation, minimum value, and maximum value of each variable. The results of descriptive analysis of the research data are contained in Table 2 below.

According to Table 2, the company's environmental performance (EP) has an average of 3.106 and deviation value of 0.547 . The standard deviation value is smaller than the average value, which indicates that the data has fairly good distribution. The average value of 3.106 means that the sample companies have made environmental management efforts according to the provisions and applicable laws or regulations. In addition, more than $77 \%$ of the observed samples in 6 years received a blue ranking at the very least. Environmental performance has the lowest value of 2 and highest value of 5 . The lowest value indicates red rank which means that environmental management had not been carried out by the company.

Sustainable report quality (SRDQ) has an average of 12.026 and deviation value of 23.534. The standard deviation value is higher than the average value, which indicates that the data has bad distribution. The quality of sustainability report disclosure has the highest value of 75 and the lowest value of zero. In this research, a value of zero means the company has not disclosed a sustainability report. More than $78 \%$ of 
companies within the observed period have not disclosed a separate sustainability report. Otherwise, the highest value means the company has provided a report following the B level of GRI guidelines.

External assurance of sustainability report (EA), as a dummy variable, has an average of 0.058 and deviation value of 0.234 . The standard deviation value is higher than the average value, which indicates that the data has bad distribution. The external assurance has the highest value of 1 and lowest value of 0 . The zero value indicates that the company does not use any external assurance for sustainability reporting, while value of 1 indicates the company uses external assurance for sustainability reporting. More than $70 \%$ of sample companies that report separate sustainability reports do not use any external assurance in their sustainability reports.

Quality of external assurance (AQ) has an average of 0.049 and deviation value of 0.204 . The standard deviation value is higher than the average value, which indicates that the data has bad distribution. The quality of external assurance has the highest value of 1 and lowest value of 0 . The zero value indicates that the company does not use any external assurance for sustainability reporting, while value of 1 indicates that the company uses a good quality external assurance based on the reporting standards used.

Company's financial access (KZ) has an average of 0.432 and deviation value of 2.918 . Company's financial access has the highest value of 6.042 and the lowest value of -22.504 . In this research, the value of a company's financial access varies. The lower the value implied to a better company's financial access.

Table 2. Descriptive Analysis of Variables

\begin{tabular}{|c|l|l|l|l|l|}
\hline Variable & Obs & Mean & $\begin{array}{l}\text { Std. } \\
\text { Dev }\end{array}$ & Min & Max \\
\hline EP & 501 & 3.106 & 0.547 & 2 & 5 \\
\hline SRDQ & 501 & 12.026 & 23.534 & 0 & 75 \\
\hline EA & 501 & 0.058 & 0.234 & 0 & 1 \\
\hline
\end{tabular}

\begin{tabular}{|c|c|c|c|c|c|}
\hline AQ & 501 & 0.049 & 0.204 & 0 & 1 \\
\hline KZ & 501 & 0.432 & 2.918 & -22.504 & 6.042 \\
\hline
\end{tabular}

\section{CONCLUSION}

From the sample of Indonesia nonfinancial public companies listed in PROPER from 2014 to 2019, there are 4 major findings in this research. First, PROPER measurement of companies environmental performance showed an average result, which means that these companies have done their responsibility in managing the environment based on the current requirements. The result also showed consistency and a disciplined attitude of some companies in managing the environment annually.

The second finding is that there is still no urgency in disclosing separate sustainability reports for most of the companies. More than 78\% of the observed companies have not disclosed seperate sustainability reports due to the inexistence of specific law and government regulations regarding this issue. This finding might also suggest the impact of law and regulation in affecting companies managerial practice and policies.

Third, this research also found that sustainability reports quality have not been considered as a priority yet. Most observed companies showed that their sustainability reports are disclosed without any presence of external assurance. Even when these companies realized the importance of external assurance role in increasing credibility and information transparency to their report.

The last finding is financial access of the companies which is measured through $\mathrm{KZ}$ index showed a high range in variative value. Moreover, although this research covers brief analysis of variables, such as environmental performance, disclosure of sustainability reports, and financial access, there could be other potential outcomes for future studies regarding this topic. Future studies can further examine the correlation between the observed variables as it is not yet identified in this research. 


\section{AUTHORS' CONTRIBUTION}

Geodita Woro Bramanti is the member of research team and corresponding author in this study

Ninditya Nareswari is the member of research team in this study

Maydawati Fidellia Gunawan is the member of research team in this study

Aang Kunaifi is the member of research team in this study

Nugroho Priyo Negoro is the member of research team in this study

\section{ACKNOWLEDGMENTS}

This research was fully funded by Department of Business Management, Institut Teknologi Sepuluh Nopember. We thank our college from Department of Business Management, especially Business, Analytic, and Strategy (BAS) Laboratory.

\section{REFERENCES}

[1] Directorate General of Climate Change, "Statistik Tahun 2018," 2019.

[2] BPS, "Statistik Lingkungan Hidup Indonesia 2019," 2019.

[3] R. Patnaik, "Impact of Industrialization on Environment and Sustainable SolutionsReflections from a South Indian Region," IOP Conference Series: Earth and Environmental Science, vol. 120, no. 1, 2018.

[4] R. Banerjee, K. Gupta and P. Mudalige, "Do environmentally sustainable practices lead to financially less constrained firms? International evidence," International Review of Financial Analysis, 2019.

[5] B. Heemskerk, P. Pistorio and M. Scicluna, "Sustainable development reporting: Striking the balance," 2002.

[6] OJK, "Infografis Lembaga Jasa Keuangan dan Emiten Penerbit Sustainability Report," Publikasi Riset dan Statistik, 2017.

[7] I. M. García-Sánchez, N. Hussain, J. Martínez-Ferrero and E. Ruiz-Barbadillo, "Impact of disclosure and assurance quality of corporate sustainability reports on access to finance," Corporate Social Responsibility and Environmental Management, pp. 1-17, 2019.
[8] H. Al-Shaer and M. Zaman, "Board gender diversity and sustainability reporting quality," Journal of Contemporary Accounting \& Economics, vol. 12, no. 3, pp. 210-222, 2016.

[9] R. Simnett, A. Vanstraelen and W. F. Chua, "Assurance on sustainability reports: An international comparison.," The Accounting Review, vol. 84, no. 3, pp. 937-967, 2009.

[10] K. Bachoo, R. Tan and M. Wilson, "Firm value and the quality of sustainability reporting in Australia," Australian Accounting Review, vol. 23, no. 1, pp. 67-87, 2013.

[11] I. B. Suratno, D. Darsono and S. Mutmainah, "Pengaruh Environmental Performance Terhadap Environmental Disclosure dan Economic Performance (Studi Empiris pada Perusahaan Manufaktur yang terdaftar di BEJ Periode 20012004)," The Indonesian Journal of Accounting Research, vol. 10, no. 2, 2007.

[12] Z. Liu, W. Li, C. Hao and H. Liu, "Corporate environmental performance and financing constraints: An empirical study in the Chinese context., 1-14.," Corporate Social Responsibility and Environmental Management, pp. 1-14, September 2020.

[13] Minister of Environment, "Peraturan Menteri Lingkungan Hidup Nomor 03 Tahun 2014 Tentang Program Penilaian Peringkat Kinerja Perusahaan Dalam Pengelolaan Lingkungan Hidup," 2014.

[14] Menteri Lingkungan Hidup dan Kehutanan, “ Program Penilaian Peringkat Kinerja Perusahaan Dalam Pengelolaan Lingkungan.," 2018.

[15] S. J. Brammer and S. Pavelin, "Corporate reputation and social performance: The importance of fit," Journal of management studies, vol. 43, no. 3, pp. 435-455, 2006.

[16] R. Gray and J. Bebbington, Accounting for the Environment, Sage, 2001.

[17] GRI, "G4 Sustainability Reporting Guidelines," 2013.

[18] A. Papoutsi and M. M. S. Sodhi, "Does disclosure in sustainability reports indicate actual sustainability performance?," Journal of Cleaner Production, vol. 260, p. 121049, 2020. 
[19] S. Yao, Y. Hong and C. M. Lin, "Environmental Information Disclosure and Financial Constraint," Asia-Pacific Journal of Financial Studies, vol. 48, no. 5, pp. 666-689, 2019.

[20] C. H. Cho, G. Michelon, D. M. Patten and R. W. Roberts, "CSR report assurance in the USA: an empirical investigation of determinants and effects," Sustainability Accounting, Management and Policy Journal, 2014.

[21] B. Cheng, I. Ioannou and G. Serafeim, "Corporate social responsibility and access to finance.," Strategic Management Journal, vol. 35, no. 1, pp. 1-23, 2014.

[22] D. Li, "Financial constraints, R\&D investment, and stock returns," The Review of Financial Studies, vol. 24, no. 9, pp. 2974-3007, 2011.

[23] S. N. Kaplan and L. Zingales, "Do investmentcash flow sensitivities provide useful measures of financing constraints?," The Quarterly Journal of Economics, vol. 112, no. 1, pp. 169-215, 1997.

[24] T. M. Whited and G. Wu, "Financial constraints risk," The Review of Financial Studies, vol. 19, no. 2, pp. 531-559, 2006.

[25] C. J. Hadlock and J. R. Pierce, "New evidence on measuring financial constraints: Moving beyond the KZ index," The Review of Financial Studies, vol. 23, no. 5, pp. 1909-1940, 2010.

[26] AccountAbility, "AA1000 Assurance Standard 2008," 2008.

[27] International Federation of Accountants, "International Standard on Assurance Engagements," 2003. 